\title{
Influence of Fibrolytic Fungus, Bacteria and Enzyme on Weight Gain and Structural Growth of Crossbred Calves
}

\author{
R. I. Kapadiya ${ }^{1 *}$, S. V. Shah ${ }^{1}$, Y. G. Patel $^{1}$ and R. Pandit ${ }^{2}$ \\ ${ }^{1}$ Livestock Research Station, College of Veterinary Science and Animal Husbandry, \\ Anand Agricultural University, Anand-388001, Gujarat, India \\ ${ }^{2}$ Gujarat Biotechnology Research center, Gandhinagar, India \\ *Corresponding author
}

\section{A B S T R A C T}

\section{Keywords}

Crossbred heifer, fibrolytic microbes, fibrolytic enzymes, body weight gain, structural growth.

\section{Article Info}

Accepted:

22 August 2019

Available Online:

10 September 2019
An experiment was planned to elucidate the influence of feeding diet (green fodder part) treated with fungi or bacteria or enzyme and 1/3 mixture of all the three on body weight, daily weight gain, and structural growth of crossbred calves. Twenty crossbred (Holstein Friesian x Kankrej) calves were allotted to five treatments (each treatment had one male and three female calves) with similar body weight and sex. Experimental animals of treatment group were offered hybrid napier treated with fungus-Aspergillus spp. $\left(1 \times 10^{7}\right.$ per $g$ feed), fibrolytic bacteria-Escherichia spp. $\left(10^{6} \mathrm{CFU}\right.$ per $\mathrm{g}$ feed $)$, xylanase $(50 \mathrm{ml} / \mathrm{kg}$ Having xylanase $1.2 \mathrm{IU} / \mathrm{ml}$ ), and $1 / 3$ dose of fungus + bacteria + enzyme together. The results revealed that average body weight at the end of experiment was $158.15 \pm 3.39 \mathrm{~kg}$. Total gain in weight and average daily gain was $72.46 \mathrm{~kg}$ and $509.36 \pm 14.09 \mathrm{~g}$, respectively with non-significant effect of fibrolytic microbes and enzymes. Feeding of fibrolytic fungus and consortia supplemented diet had reduced $(\mathrm{P}<0.05)$ body length whereas effect of feeding fibrolytic bacteria and enzyme resulted in similar body length. Average heart girth significantly reduce $(\mathrm{P}<0.05)$ on feeding fibrolytic bacteria, enzymes and consortium supplemented diet of crossbred heifers in comparison to control and heart girth of fibrolytic fungus fed heifers was at par with control. In conclusion feeding hybrid napier treated with fibrolytic fungus, bacteria, enzymes and consortia to crossbred heifers was without improvement in weight gain and structural body growth.

\section{Introduction}

Proper management of young stock in terms of optimal nutritional care (Anonymous, 2012) is needed to increase milk production and income. The available feed resources like dry roughages, green fodder, concentrate and crop residue are inadequate and costly to meet nutrient requirement for growing bovines. The feed shortage could be overcome by use of alternative feed technologies (Walli et al., 2006), which may lead to increase in nutrient supply within the ruminant system. One of the primary factors affecting livestock production is fiber digestibility, with often less than 600 $\mathrm{g} / \mathrm{kg}$ of dietary fiber being digested by the animal (Van Soest 1994).In recent years, there has been use of microbial products as feed 
additives in ruminant diets to resolve feed related problem. Microorganisms produce different groups of enzymes and help to degrade cellulosic material. They have been isolated from rumen fungi and bacteria which can improve feed intake as well as growth and feed efficiency of young ones. Authors reported an increase in the digestion of fibre and improved animal performances by using feed additive (Adesogan et al., 2007; Bala et al., 2009). Direct fed microbes (DFM) with exogenous fibrolytic enzyme (EFE) had considerable beneficial influence on growth performance and feed conversion efficiency of the crossbred calves without causing adverse effect on behavioural traits (Kocyigit et al., 2016). However, many have reported either no effect at all or sometimes negative effect (Baloyi, 2008).Many researchers reported that yeast culture improved feed intake (Ayad et al., 2013); feed conversion efficiency, growth rate (Kumar et al., 2015) and nutrient digestibility (Sehgal et al., 2008) in cost effective manners (Hutjens, 2003). Fibrolytic enzymes are added in ruminant diets to improve nutrient digestibility (Lunagariya, 2019), and growth rate (Dean et al., 2013). Influences of DFM on growth traits of dairy calves have not been adequately studied and the findings reported in literature are inconsistent (Elghandour et al., 2015).

Considering above facts in mind, the present study was planned to observe the influence of feeding green fodder treated with either fungi or bacteria or enzyme or all three mix on total body weight gain, daily weight gain, body length and heart girth of crossbred calves.

\section{Materials and Methods}

The study was conducted at Livestock Research Station, AAU, Anand for 140 days as per guideline of Institutional Animal Ethics Committee (Sanction No. 285/LPM/2018) of College of Veterinary science and Animal
Husbandry, Anand Agricultural University, Anand. Twenty crossbred (Holstein Friesian $50 \%$ x Kankrej 50\%) calves were allotted to five treatments (each treatment had one male and three female calves) with similar body weight $(85.70 \pm 6.37 \mathrm{~kg})$ and age $(167.55 \pm$ 21.70 days).

To meet nutrient requirements (ICAR, 1998), all calves were individually fed green hybrid napier (Coimbatore-3 variety), concentrate and sorghum hay. The exogenous fibrolytic microbes and enzymes use in this experiment were isolated and purified from animals of this farm by the Department Animal Biotechnology, Veterinary College, AAU, Anand. The experimental animals were kept let loose for two hours (8:00 to 10:00) in morning for exercise during which wholesome clean drinking water was available. Drinking water was also offered two times in afternoon and night hrs. Measured quantity of hybrid napier (treated and untreated), concentrate and sorghum hay were offered to animals at 10:00, 14:00 and 16:00 hrs, respectively.

Experimental animals of control group were offered untreated hybrid napier and other groups were offered hybrid napier treated with fungus- Aspergillus spp. $\left(1 \times 10^{7}\right.$ per $\mathrm{g}$ feed $)$, fibrolytic bacteria-Escherichia spp. $\left(10^{6} \mathrm{CFU}\right.$ per $\mathrm{g}$ feed $)$, xylanase $(50 \mathrm{ml} / \mathrm{kg}$ having xylanase $1.2 \mathrm{IU} / \mathrm{ml}$ ), and $1 / 3$ dose of fungus + bacteria + enzyme to animals of Fungus fed $(\mathrm{FF})$, Bacteria fed (BF), Enzyme fed (EF) and Consortium fed (CF), respectively. Two kilogram of hybrid napier for treatment group calves was thoroughly mixed with fungus, bacteria, enzymes and consortium before 20 hrs of feeding as per treatment and were covered with plastic sheet on cemented floor and again mixed two time before feeding. Treated hybrid napier was equally distributed among the calves of treatment considering moisture loss at time of feeding. Quantity of hybrid napier and concentrate was fed to 
calves so as to without left over and sorghum hay was offered ad libitum to fulfill remaining nutrient requirement. Leftover of fodder was measured on the next day morning. Feed and fodder was adjusted at biweekly intervals as per body weight of animals. Weekly dry matter and crude protein of feed and fodders were analyzed as per AOAC (1995). The weight of the all experimental animals was recorded for two consecutive days at biweekly interval in morning between 8.00 to $8.30 \mathrm{hrs}$ on weighbridge before feeding and watering after taking left over. Average of the two days was considered as the final weight. The difference in body weight between two biweekly intervals was considered as the weight gain. Body measurement viz., heart girth and length of animals were also measured biweekly using standard measure tape. The body length was taken from point of shoulder to pin bone while the heart girth was measured taking the circumference from behind the hump and behind the brisket. All the measurements were taken by keeping the animals on flat floor while standing in normal position. An experimental design was Completely Randomized Designas and the data was analyzed by per Snedecor and Cochran (2002).

\section{Results and Discussion}

\section{Body weight and growth rate}

Proximate composition of concentrate and fodder is given in table 1. DM and nutrients intake of experimental animals was offered as per requirement (ICAR, 1998). Average biweekly body weight of crossbred calves recorded during the experiment is given in table 2.The difference in body weight of experimental animals was statistically nonsignificant at initiation as well as at the end of the experiment. Average body weight of experimental animals at the end of experiment was $158.15 \pm 3.39 \mathrm{~kg}$. Total gain $(72.46 \mathrm{~kg})$ and average daily gain (509.36 \pm 14.09$)$ in body weight followed the same trends.

Similar growth rate in calves was reported by Di Francia et al., (2008) using fungus supplement (451 to $529 \mathrm{~g} / \mathrm{head} /$ day), Bayatkouhsar et al., (2013) using probiotic (549 g/head/day.), Geiger et al., (2014) using milk replacer with DFM (520 g/head/day), Kumar et al., (2015) using anaerobic fungal zoospores $\quad(515.52 \pm 20.11 \mathrm{~g} / \mathrm{head} /$ day $)$, Shahzad et al., (2016) using fungus (480 to $560 \mathrm{~g} / \mathrm{head} /$ day), Sharma et al., (2018) using probiotic (494.6 g/head/day).However, higher growth rate in calves than current study was noted by Dey et al., (2004) using ruminal fungi (709 g/head/day), Lascano et al., (2009) using Saccharomyces cerevisiae $(800 \pm 0.01$ $\mathrm{g} /$ head/day), Sehgal et al., (2008) using anaerobic fungi Neocallimastix sp. (659.81 $\mathrm{g} /$ head/day).While Khuntia and Chaudhary (2002) had reported lower growth rate (366 g) of calves on feeding lactic acid producing bacteria (LAB).

Feeding direct-fed microbial supplemented milk replacer in Holstein calves (Geiger et al., 2014) revealed non-significant effect on body weight and average daily gain. Similarly average daily gain of crossbred (zebu x brown swiss) steers was also non-significant on feeding exogenous fibrolytic enzymes @ 2, 4 and $6 \mathrm{ppm}$ in diet containing $88 \%$ concentrate and $12 \%$ forage (dry basis) for 75 days.

Dean et al., (2013) also reported only numerically increase $(\mathrm{P}>0.05)$ in body weight gain of Holstein cows on feeding fibrolytic enzyme applied at ensiling to bermuda grass $(1.3 \mathrm{~g} / \mathrm{kg} \mathrm{DM})$ as well as direct feeding to animal, mixing and then feeding with concentrate, forage or total mixed ration (4 $\mathrm{g} /$ head/day).The feeding Saccharomyces cerevisiae at $1 \mathrm{~g} / \mathrm{kg}$ feeding high and lowconcentrate diets of 32 Holstein heifers showed similar average daily gain $(0.80 \pm$ 
$0.01 \mathrm{~kg} / \mathrm{d}$ )at the end of the experiment (Lascano et al., 2009). Contrary to current findings, feeding probitics and exogenous fibrolytic enzymes in milk or milk replacer at early age of buffalo and crossbred calves had significant effect on body weight and average daily gain.

Sharma et al., (2018) revealed that daily feeding probiotic fermented milk (Lactobacillus acidophilus; $10^{8} \mathrm{CFU} / \mathrm{ml}$ )@ $200 \mathrm{ml}$ to Murrah buffalo calves resulted in higher $(\mathrm{P}<0.05)$ final body weight $(86.24$ vs. $83.63 \mathrm{~kg}$ )and daily gain (454.8 vs. $433.9 \mathrm{~g}$ ) in comparison to control basal diet (concentrate mixture and green fodder) during a 120 days experiment.

Similarly, Sharma et al., (2016) concluded that feeding probiotic (Saccharomyces cerevisiae)@15g/calf/day in milk for a period of two months resulted in improved $(\mathrm{P}<0.05)$ growth rate of buffalo calves under field condition. Feeding of direct fed microbes (Lactobacillus acidophilus, Lactobacillus casei, Lactobacillus plantarum, Bacillus subtilis and Aspergillus oryzae) and exogenous fibrolytic enzymes (pectinase, lipase, protease, amylase and cellulase) @ 10 $\mathrm{g}$ per animal to Brown Swiss $\mathrm{x}$ Eastern Anatolian RedF1 calves resulted higher $(\mathrm{P}<0.05)$ weights and growth rate than control group (Kocyigitet al., 2016). Fibrolytic microbes and enzymes feeding had no effect on body weight and average weight gain in crossbred calves after post weaning age.

Tripathi et al.,(2007) indicated significant average daily gain and non significant body weight of Murrah buffalo calves (age about 10 months) fed a complete feed mixture consisted of $50 \%$ wheat straw and $50 \%$ concentrate supplemented with Orpinomyces sp. C-14 and Piromyces sp. WNG-12 cultures $\left(10^{6}\right.$ thallus forming units per $\mathrm{ml}$ ). Feeding fungal culture $\left(10^{6} \mathrm{CFU} / \mathrm{ml}\right) 160 \mathrm{ml}$ per calf per week supplemented diet (50\% wheat straw and 50\% concentrate) showed significant $(\mathrm{P}<0.05)$ gain in body weight $(709.3 \pm 59.03$ and $614.8 \pm 56.92$ $\mathrm{g}$ /day) in Tharparkar $\times$ Holstein-Friesian calves (Dey et al., 2004).

\section{Body Length and Heart girth}

Body length at beginning and end of the experiment was $33.78 \pm 0.45$ and $43.23 \pm 0.51$ inch, respectively with $27.97 \%$ increase and was without significant effect among treatments. Feeding of fibrolytic fungus and consortium supplemented diet had reduced $(\mathrm{P}<0.05)$ body length whereas effect of feeding fibrolytic bacteria and enzyme resulted in similar body length.

During experiment heart girth improved by $17.12 \%$ (7.17 inch) from $41.88 \pm 0.45$ to $49.05 \pm 0.42$ inch final with non significant effect. Average heart girth of crossbred heifers was significantly reduced $(\mathrm{P}<0.05)$ on feeding fibrolytic bacteria, enzymes and consortium supplemented diet in comparison to control, whereas heart girth of fibrolytic fungus fed heifers was statistically at par with control. Similarly Kocyigit et al., (2016) concluded that the feeding of direct fed microbes (Lactobacillus acidophilus, Lactobacillus casei, Lactobacillus plantarum, Bacillus subtilis and Aspergillus oryzae) and exogenous fibrolytic enzymes (pectinase, lipase, protease, amylase and cellulase) @ 10 $\mathrm{g}$ per animal to Brown Swiss $\mathrm{x}$ Eastern Anatolian RedF1 calves were without effect on gain in body measurements like body length and heart girth. Ghazanfar et al., (2015) also reported non-significant reduction in body height $(84.13 \pm 1.60$ vs. $78.34 \pm 1.14 \mathrm{~cm})$ and body length $(79.36 \pm 1.83$ vs. $78.53 \pm 2.12$ $\mathrm{cm})$, whereas heart girth improved (86.38 \pm 1.56 vs. $89.13 \pm .0 .62 \mathrm{~cm}$ ) non-significant of Sahiwal heifers feeding diet supplemented with yeast (Saccharomyces cerevisiae) @ $5 \mathrm{~g}$ daily for 120 days feeding trial. 
Table.1 Proximate composition of the ingredients and feeds

\begin{tabular}{|l|l|l|l|l|l|l|}
\hline Feeds/Fodders & DM \% & CP \% & CF \% & EE \% & NFE \% & Ash \% \\
\hline $\begin{array}{l}\text { Compound } \\
\text { concentrate }\end{array}$ & 90.50 & 25.08 & 10.52 & 2.89 & 56.04 & 13.28 \\
\hline \begin{tabular}{l} 
Sorghum Hay \\
\hline $\begin{array}{l}\text { Hybrid Napier } \\
\text { (CO3) }\end{array}$
\end{tabular} & 23.70 & 8.46 & 31.23 & 2.58 & 40.95 & 12.49 \\
\hline
\end{tabular}

Note: $\mathrm{DM}=$ dry matter, $\mathrm{CP}=$ crude protein, $\mathrm{CF}=$ crude fibre, $\mathrm{EE}=$ ether extracts, $\mathrm{NFE}=$ nitrogen free extracts, $\mathrm{CO} 3=$ Coimbatore 3

Table.2 Body weight and growth of crossbred calves

\begin{tabular}{|c|c|c|c|c|c|}
\hline \multirow[t]{2}{*}{ Attributes } & \multicolumn{4}{|c|}{ Dietary groups } & \multirow[b]{2}{*}{$\begin{array}{l}\text { Consortium } \\
\text { fed (CF) }\end{array}$} \\
\hline & Control (C) & $\begin{array}{l}\text { Fungus fed } \\
\text { (FF) }\end{array}$ & $\begin{array}{c}\text { Bacteria fed } \\
\text { (BF) }\end{array}$ & $\begin{array}{l}\text { Enzyme fed } \\
\text { (EF) }\end{array}$ & \\
\hline \multicolumn{6}{|c|}{ Body weight (kg) } \\
\hline Initial BW & $85.60 \pm 8.78$ & $85.95 \pm 5.05$ & $85.35 \pm 6.17$ & $85.60 \pm 7.39$ & $85.95 \pm 4.48$ \\
\hline Final BW & $159.15 \pm 10.32$ & $158.65 \pm 6.24$ & $155.75 \pm 9.16$ & $158.35 \pm 10.45$ & $158.85 \pm 4.66$ \\
\hline Total gain & $73.55 \pm 3.05$ & $72.70 \pm 2.43$ & $70.40 \pm 4.23$ & $72.75 \pm 3.27$ & $72.90 \pm 0.33$ \\
\hline \multicolumn{6}{|l|}{ Daily Growth } \\
\hline $\begin{array}{l}\text { ADG } \\
\text { (g/head/day) }\end{array}$ & $514.28 \pm 32.37$ & $512.14 \pm 31.03$ & $493.21 \pm 30.79$ & $524.64 \pm 30.14$ & $521.07 \pm 34.69$ \\
\hline \multicolumn{6}{|c|}{ Body length (inch) } \\
\hline Initial & $35.25 \pm 0.75$ & $32.75 \pm 0.85$ & $33.62 \pm 0.94$ & $34.50 \pm 1.19$ & $32.75 \pm 1.13$ \\
\hline Final & $44.00 \pm 0.84$ & $42.75 \pm 1.49$ & $43.50 \pm 0.54$ & $43.65 \pm 1.84$ & $42.25 \pm 0.97$ \\
\hline Average & $39.68^{\mathrm{B}} \pm 0.49$ & $38.55^{\mathrm{A}} \pm 0.57$ & $39.89^{B} \pm 0.53$ & $39.91^{B} \pm 0.59$ & $38.66^{A} \pm 0.56$ \\
\hline Total gain & $8.75 \pm 0.92$ & $10.00 \pm 0.72$ & $9.88 \pm 0.43$ & $9.15 \pm 1.16$ & $9.50 \pm 0.35$ \\
\hline \multicolumn{6}{|c|}{ Heart girth (inch) } \\
\hline Initial & $41.62 \pm 1.77$ & $42.37 \pm 0.55$ & $41.37 \pm 1.16$ & $42.25 \pm 0.85$ & $41.75 \pm 0.83$ \\
\hline Final & $50.12 \pm 1.33$ & $49.12 \pm 0.43$ & $48.12 \pm 1.43$ & $49.00 \pm 0.71$ & $48.87 \pm 0.59$ \\
\hline Average & $46.24^{C} \pm 0.56$ & $45.57^{\mathrm{BC}} \pm 0.40$ & $44.59^{\mathrm{A}} \pm 0.49$ & $45.19^{\mathrm{AB}} \pm 0.44$ & $44.88^{\mathrm{AB}} \pm 0.40$ \\
\hline Total gain & $8.50 \pm 0.84$ & $6.75 \pm 0.14$ & $6.75 \pm 0.60$ & $6.75 \pm 0.48$ & $7.12 \pm 0.52$ \\
\hline
\end{tabular}

Mean values bearing different superscript in a row differ significantly $(\mathrm{P}<0.05)$

Note: $\mathbf{A D G}=$ Average daily gain

Mean values with different superscript within a row differ significantly $(\mathrm{P}>0.05)$

A trial reported that heart girth $(81.16 \mathrm{~cm}$ and $78.49 \mathrm{~cm})$ was significantly $(\mathrm{P} \leq 0.05)$ higher and body length (65.27 and $66.54 \mathrm{~cm})$ was non-significantly higher of Holstein calves fed with a standard milk replacer/concentrate diet supplemented with $1 \mathrm{~g}$ probiotic powder (Lactobacillus animalis, Lactobacillus paracasei, Bacillus coagulans, having $1.8 \times$
$10^{10} \mathrm{CFU} / \mathrm{g}$ ) during the first month of life as reported by Agazzi et al., (2014). Bayatkouhsar et al., (2013)also showed nonsignificant $(\mathrm{P}>0.05)$ effect on the final body length and heart girth of Holstein calves on feeding laboratory and commercial produced probiotic both@2.0 × $10^{8} \mathrm{CFU}$ per day in morning milk feeding. 
Lascano et al., (2009) also indicated that there was no effect of Saccharomyces cerevisiae addition @ $1 \mathrm{~g} / \mathrm{kg}$ feed on structural measurement (heart girth and body length) of Holstein heifers for period of 133 days.

Contrary to present experiment, Sharma et al., (2018) revealed that daily feeding of probiotic fermented milk (Lactobacillus acidophilus; $10^{8} \mathrm{CFU} / \mathrm{ml}$ )@200 ml for 120 days to Murrah buffalo calves lead to significant $(\mathrm{P}<$ 0.05)increase in heart girth (104.26 vs. 98.54 $\mathrm{cm}$ ) in comparison to control basal diet (concentrate mixture and green fodder).

Crossbred heifers fed diets with hybrid napier which treated with fungus- Aspergillusspp. (1× $10^{7}$ per $\mathrm{g}$ feed), fibrolytic bacteriaEscherichia spp. $\left(10^{6} \mathrm{CFU}\right.$ per g feed), xylanase $(50 \mathrm{ml} / \mathrm{kg}$ having xylanase 1.2 $\mathrm{IU} / \mathrm{ml}$ ), and $1 / 3$ dose of fungus + bacteria + enzyme was without improvement in total weight gain, growth rate, body length and heart girth.

Laboratory produced fibrolytic microbes and enzymes needs improvement to be effective on growth rate and structure improvement in crossbred heifers.

\section{References}

Adesogan, A. T., Kim, S. K., Arriola, G., Dean, D. B. and Staples, C. R. (2007). Strategic addition of dietary fibrolytic enzymes for improved performance of lactating dairy cows. Florida Ruminant Nutrition Symposium, held at University of Florida, Gainesville, January 30-31.

Agazzi, A., Tirloni, E., Stella, S., Maroccolo, S., Ripamonti, B., Bersani, C. and Savoini, G. (2014). Effects of speciesspecific probiotic addition to milk replacer on calf health and performance during the first month of life. Annals of Animal Science, 14(1): 101-115.
Anonymous (2012). National Dairy Development Board. Livestock population in India by species. Retried from http://www.nddb.org/English/statistics/. AOAC. (1995). Official Methods of Analysis. 16th ed. Association of Official Analytical Chemists, Washington, DC.

Ayad, M. A., Benallou, B., Saim, M. S., Smadi, M. A. and Meziane, T. (2013). Impact of feeding yeast culture on milk yield, milk components, and blood components in Algerian dairy herds. Journal of Veterinary Sciences and Technology, 4: 135-140.

Bala, P., Malik, R. and Srinivas, B. (2009). Effect of fortifying concentrate supplement with fibrolytic enzymes on nutrient utilization, milk yield and composition in lactating goats. Animal Science Journal, 80(3): 265-272.

Baloyi, T. F. (2008). Effects of exogenous fibrolytic enzymes on in vitro fermentation kinetics of forage and mixed feed substrates (Doctoral dissertation, University of Stellenbosch).

Bayatkouhsar, J., Tahmasebi, A. M., Naserian, A. A., Mokarram, R. R. and Valizadeh, R. (2013). Effects of supplementation of lactic acid bacteria on growth performance, blood metabolites and fecal coliform and lactobacilli of young dairy calves. Animal Feed Science and Technology, 186(1): 1-11.

Dean, D. B., Staples, C. R., Littell, R. C., Kim, S. C. and Adesogan, A. T. (2013). Effect of method of adding a fibrolytic enzyme to dairy cow diets on feed intake digestibility, milk production, ruminal fermentation and blood metabolites. Animal Nutrition and Feed Technology, 13: 337-353.

Dey, A., Sehgal, J. P., Puniya, A. K.and Singh, K. (2004). Influence of an anaerobic fungal culture (Orpinomyces sp.) administration on growth rate, 
ruminal fermentation and nutrient digestion in calves. Asian Australasian Journal of Animal Sciences, 17(6): 820824.

Di-Francia, A., Masucci, F., De-Rosa, G., Varricchio, M. L. and Proto, V. (2008). Effects of Aspergillus oryzae extract and a Saccharomyces cerevisiae fermentation product on intake, body weight gains and digestibility in buffalo calves. Animal Feed Science and Technology, 140(1-2): 67-77.

Elghandour, M. M. Y., Salem, A. Z. M., Casteneda, J. S. M., Camacho, L. M., Kholif, A. E. and Chagoyan, J. C. V. (2015). Direct-fed microbes: A tool for improving the utilization of low quality roughages in ruminants. Journal Integrative Agriculture, 14: 526-533.

Geiger, A. J., Ward, S. H., Williams, C. C., Rude, B. J., Cabrera, C. J., Kalestch, K. N. and Voelz, B. E. (2014). Effects of increasing protein and energy in the milk replacer with or without direct-fed microbial supplementation on growth and performance of preweaned Holstein calves. Journal of Dairy Sciences, 97(11), 7212-7219.

Ghazanfar, S., Anjum, M. I., Azim, A. and Ahmed, I. (2015). Effects of dietary supplementation of yeast (Saccharomyces cerevisiae) culture on growth performance, blood parameters, nutrient digestibility and fecal flora of dairy heifers. Journal of Animal and Plant Sciences, 25(25): 53-9.

Hutjens, M. F. (2003). Economics of feed additives. Penn State Dairy Cattle Nutrition Workshop. dasweb.psu.edu/pdf/hutjens1.pdf.

January, 2006. pp.39-46.

ICAR. (1998). Nutrient Requirements of Livestock and Poultry, $2^{\text {nd }}$ Revised Edition (Edt. By S.K. Ranjhan) Indian Council ofAgricultural Research, Krishi Anusandhan Bhavan, Pusa, NewDelhi-
110012, India.

Khuntia, A. and Chaudhary, L. C. (2002). Performance of male crossbred calves as influenced by substitution of grain by wheat bran and the addition of lactic acid bacteria to diet. Asian Australasian Journal of Animal Sciences, 15(2): 188194.

Kumar, S., Sehgal, J. P., Puniya, A. K. and Kumari, R. (2015). Growth performance and fibre utilization of Murrah male buffalo calves fed wheat straw based complete feed blocks incorporated with superior anaerobic fungal zoospores (Neocallimastix sp. GR-1). The Indian Journal of Animal Sciences, 85(3): 27581.

Kocyigit, R., Aydin, R., Yanar, M., Diler, A., Avci, M. and Ozyurek, S. (2016). The effect of direct-fed microbials plus exogenous feed enzyme supplements on the growth, feed efficiency ratio and some behavioural traits of Brown Swiss $\mathrm{x}$ Eastern Anatolian Red F1 Calves. Pakistan Journal of Zoology, 48(5): 1389-1393.

Lascano, G. J., Zanton, G. I., Suarez-Mena, F. X. and Heinrichs, A. J. (2009). Effect of limit feeding high-and low-concentrate diets with Saccharomyces cerevisiae on digestibility and on dairy heifer growth and first-lactation performance. Journal of Dairy Science, 92(10): 5100-5110.

Lunagariya, P M., Gupta, R. S., Shah, S. V., \& Patel, Y. G. (2019). Digestibility of Nutrients as Influenced by Supplementation of Exogenous Fibrolytic Enzymes in Dry NonPregnant Cows. The Indian Journal of Veterinary Sciences and Biotechnology, 14(04), 45-48.

Shahzad, F., Abdullah, M., Chaudhry, A. S., Bhatti, J. A., Jabbar, M. A., Ahmed, F. and Irshad, I. (2016). Effects of varying levels of fungal (Arachniotus sp.) treated wheat straw as an ingredient of total 
mixed ration on growth performance and nutrient digestibility in Nili Ravi buffalo calves. Asian-Australasian Journal of Animal Sciences, 29(3): 359.

Sharma, A. N., Kumar, S. and Tyagi, A. K. (2018). Effects mannan- oligosaccharides Lactobacillus supplementation on growth performance, nutrient utilization and faecal characteristics in Murrah buffalo calves. Journal of Animal Physiology and Animal Nutrition, 102(3): 679-689.

Sharma, P. K., Prajapati, K. A. and Choudhary, M. K. (2016). Effect of probiotic supplementation on growth performance of pre-ruminant buffalo calves. Journal of Krishi-Vigyan, 4(2): 37-39.

Sehgal, J. P., Jit, D., Puniya, A. K. and Singh, K. (2008). Influence of anaerobic fungal administration on growth, rumen fermentation and nutrient digestion in female buffalo calves. Journal of Animal and Feed Sciences, 17: 510-518.

Snedecor, G.W. and Cochran, W.G. (2002). Statistical Methods. 8th ed. Affiliated East-West Press Pvt. Ltd., New Delhi.

Tripathi, V. K., Sehgal, J. P., Puniya, A. K. and Singh, K. (2007). Hydrolytic activities of anaerobic fungi from wild blue bull (Boselaphustrago camelus). Anaerobe, 13(1): 36-39.

Van-Soest, P. J. (1994). Gastro-intestinal fermentations. In nutritional ecology of the ruminant. Ruminant metabolism, nutritional strategies, the cellulolytic fermentation and the chemistry of forages and plant fibers. Cornell University Press, Ithaca, NY, 152-177.

Walli, T. K.; Sirohi, S. K. and Kumar, S. (2006). Bypass nutrient technologyscope precision-fed dairy heifers. Journal of Dairy Science, 95(6): 32983309.

\section{How to cite this article:}

Kapadiya, R. I., S. V. Shah, Y. G. Patel and Pandit, R. 2019. Influence of Fibrolytic Fungus, Bacteria and Enzyme on Weight Gain and Structural Growth of Crossbred Calves. Int.J.Curr.Microbiol.App.Sci. 8(09): 2385-2392. doi: https://doi.org/10.20546/ijcmas.2019.809.276 